\title{
TTR
}

Traduction, terminologie, rédaction

\section{Georges L. Bastin and Paul F. Bandia, eds. Charting the Future of Translation History. Ottawa, University of Ottawa Press, 2006, 344 p.}

\section{Jorge Jiménez Bellver}

Volume 21, numéro 1, 1er semestre 2008

La formation en traduction : pédagogie, docimologie et technologie I

Translator Training: Pedagogy, Evaluation, and Technologies I

URI : https://id.erudit.org/iderudit/029694ar

DOI : https://doi.org/10.7202/029694ar

Aller au sommaire du numéro

\section{Éditeur(s)}

Association canadienne de traductologie

ISSN

0835-8443 (imprimé)

1708-2188 (numérique)

Découvrir la revue

Citer ce compte rendu

Jiménez Bellver, J. (2008). Compte rendu de [Georges L. Bastin and Paul F. Bandia, eds. Charting the Future of Translation History. Ottawa, University of Ottawa Press, 2006, 344 p.] TTR, 21(1), 256-262. https://doi.org/10.7202/029694ar

Tous droits réservés (C) TTR: traduction, terminologie, rédaction — Les auteurs, 2009
Ce document est protégé par la loi sur le droit d'auteur. L’utilisation des services d'Érudit (y compris la reproduction) est assujettie à sa politique d'utilisation que vous pouvez consulter en ligne.

https://apropos.erudit.org/fr/usagers/politique-dutilisation/ 
even realizing it, offered in the book's title and the Wilbur poem an antidote to such cynicism. Why should theoretical discourse be "insufficient," "a dead end"? Is it not, like any placid surface of the world, forever subject to transformation, a sea-change, to the self-sundering wrought by the Real? Should the conviction of theory's insufficiency manifest as a bitter disappointment, or as a "second finding," a "loss back to wonder"?

\section{Ryan Fraser University OF OtTAWA}

\section{Georges L. Bastin and Paul F. Bandia, eds. Charting the Future of Translation History. Ottawa, University of Ottawa Press, 2006, 344 p.}

If a single keyword were to be selected from all 17 essays that make up Charting the Future of Translation History, that would be "gaps". This collection of studies, drawn from the XVII ${ }^{\text {th }}$ Annual Conference of the Canadian Association for Translation Studies (CATS), attempts to point at several lacunae surrounding research on the history of translation since the mid-1960s. Contributors discuss both translation as the object of historical study and history as the object of translation studies-i.e. the role of translation in the (de)construction of history.

The book is divided into two main blocks: 'Methodology' and 'Current Discourses.' In the former, seven renowned specialists discuss contemporary discourses on translation research; in the latter, ten case studies map translation in geographical and temporal zones. "Blank Spaces in the History of Translation" by Julio-César Santoyo reflects on neglected areas of translation and interpreting studies while summarizing the history of oral interpretation, intracultural translation, pseudo and selftranslations, and translational mistakes. Particularly remarkable is his approach regarding the silent protagonism of translation in the construction of history, and the need to de-Westernize it by exposing texts outside the European tradition. 
Conversely, Georges L. Bastin's "Subjectivity and Rigour in Translation History: The Latin American Case" revisits Western translation methodologies, revealing their inapplicability to alternative sociocultural realities. Bastin proposes a new paradigm for translation history in Latin America rooted in hybridity, contradictory totality, and non-dialectical heterogeneity. An autochthonous cultural model recognizes a Latin American contradictory and heterogeneous subjectivity, demanding a historical periodization specific to this particular conceptual framework, a task to which translation turns out central.

Likewise, Clara Foz regards periodization useful in "Translation, History and the Translation Scholar", but also partial and arbitrary. Through the analysis of the shifts in methodologies from positivist objectivity to post-structuralist deconstruction, Foz underscores that the role of history serves the ideologicallymotivated and inaccurate delimitation of temporal stages, and reinforces cultural domination.

Paul F. Bandia's "The Impact of Postmodern Discourse on the History of Translation" posits that the overlapping of translation history with a Eurocentric conception of nationstates has shaped the sequential, homogenizing perspective in cultural studies prior to deconstructionist approaches. In this context, the task of the history of translation becomes, rather than reinforcing national boundaries, blurring them while raising a global, multicultural awareness and, like poststructuralist views have displayed, undo the linearity of history.

Like Bandia, Reine Meylaerts criticizes the perspective of European nation-states on societal frameworks. "Conceptualizing the Translator as a Historical Subject in Multilingual Environments: A Challenge for Descriptive Translation Studies?" utilizes recent insights à propos Pierre Bourdieu's habitus as plural and dynamic, as well the views of the translator as a historical subject displayed by Descriptive Translation Studies. Meylaerts focuses on a specific framework-literary translations from Flemish into French in interwar Belgium - to illustrate the role of translation in the delegitimization of certain tongues as literary languages and the perpetuation of the sociocultural superiority of 
others, to reveal the decisive role that translational choices (i.e. habituses) play in the relationship among territory, language, literature, and people as circumscribed by institutional and discursive structures. She concludes with a call for a redefinition of "source" and "target" to enable a flexible, communicationoriented perspective.

Sergia Adamo's "Microhistory of Translation" is another invitation to rethink the representation of historically marginalized subjects. Rejecting hermetic models that reconstruct the past via seemingly objective historical data, microhistory favors narrations of collective memory from minor, fragmentary, and disrupting data, a necessary step towards a more inclusive history of translation.

Last but not least in the first section, Jesús BaigorriJalón's "Perspectives on the History of Interpretation: Research Proposals" tackles gaps in the history of interpretation, one of the most deeply rooted modalities of cultural interaction. BaigorriJalón points that the orality of interpreting and its secondary status are challenges to a historical research that could enable our prediction of future trends- "A Past for Our Future", as the author puts it. In order to contribute to systematizing the study of the history of interpretation, Baigorri-Jalón presents a list of 17 research proposals arranged according to four main criteria: topics, sources, methods, and difficulties. The purpose of such a list lies not only in grasping the interest of researchers, but also in raising awareness of the significance of the history of the profession and the significant ways in which it may inform future scholarship.

The second block of the book is articulated both diachronically and geographically around the political, sociocultural, and ideological components that have governed translational practices. In "Literalness and Legal Translation," Claire-Hélène Lavigne starts by questioning the literality of legal translation as influenced by its authoritative position, a persistent practice even in twenty-first century translation studies. Drawing on the French translation of Corpus Iuris Civilis and analyzing translational strategies like versification and synonymy, the author 
illustrates how the "interventionist approach" of the translator destabilized the text with pedagogical purposes, in spite of the certainly authoritative status of the text during the Middle Ages.

Also focusing on a particular genre-albeit within a contemporary time frame-, Chantal Gagnon takes the reader to the heart of identity construction in Canadian political speeches in "Ideologies in the History of Translation." Examining a corpus of seven speeches that were delivered in both French and English in situations of national crisis from the framework of Critical Discourse Analysis, Gagnon's study departs from the concept of "translation strategies" and draws attention to "translation shifts" in order to account for the ideological dimensions of translation. Hence, in her article she exposes how the translation of political speeches is determined by variables such as the historical context, the place of publication, and the targeted audience, all of them of particular importance for the investigation of translation history.

Another recurring trend within the second section deals with individual translators and/or writers throughout history, a field of research which the contributions by Marilyn Gaddis Rose, James St. André, Juan Miguel Zarandona, Jo-Anne Elder, and Christine York tackle from different angles. In "The Role of Translation in History: The Case of Malraux", Gaddis Rose compares translations of twentieth-century French writer André Malraux to expose a Benjaminian reading of translation: the English renditions of his novels Les Conquérants and $\mathrm{La}$ Condition bumaine - which were published shortly after their French counterparts and read as fictional accounts of the French colonial presence in China-revealed subsequent historical events in the colonial empires and eventually contributed to a deeper understanding of the covert imperialist and self-destructive traces of the original texts, underlining in this way the contribution of translational activity to historiography.

Also inspired by Eurocentric representations of China, James St. André discusses in "Long Time No See, Coolie': Passing as Chinese through Translation" how, on the one hand, the notion of "Chineseness" in nineteenth-century England was produced by translations of Chinese literature and, on the 
other, the way that such "Chineseness" in turn inspired English writer Ernest Bramah Smith's pseudo-translations. With that goal in mind, the author creates significant parallels between the strategies used by Smith and the concept of slumming as it has been developed in African-American studies and queer theory to show how nineteenth-century sinological translation caricatured the Chinese as a means to delineate the boundaries between certain ethnic groups and social classes or, in other words, between the Self and the Other.

The figure of early nineteenth-century writer and translator Robert Southey as a role model for future professionals inspires Juan Miguel Zarandona's article, "The Amadis of Gaul (1803) and The Chronicle of Cid (1808) by Robert Southey: The Medieval History of Spain Translated". By means of a translation comparison among two Spanish medieval novels and several successive English renditions and an examination of Southey's reflections on translational activity, the author's contribution clearly reflects, as was remarked in the introductory lines, the paradigmatic interdependence between the role of history in translation studies and the role of translation in the shaping of history: while Southey's translations were commissioned as a result of a revived interest in Spain in late eighteenth-century Britain, those same translations allowed for a revival of medieval chronicles and, even more importantly, a unique hybridization of several different literary genres, exposing the dynamic power of translation to provide seemingly forgotten texts with an afterlife, as Gaddis Rose also argued.

On this matter, Jo-Anne Elder's source-oriented dissection of the transformative impact of translated texts stands out as a new example of the impact of translation on the course of history. "Keepers of the Stories: The Role of the Translator in Preserving Histories" is inspired by Canadian contemporary translator Robert Binghurst-who specializes in translations of stories and poems told by Haida mythtellers in Aboriginal languages - as a model of the translator's potential and responsibility to preserve and reinforce endangered literatures historically obliterated by dominant cultures, a translatorempowering approach that certainly goes along the lines of 
Lawrence Venuti's The Translator's Invisibility and the more recent Enlarging Translation, Empowering Translators, by Maria Tymoczko.

Christine York's “Translating the New World in Jean de Léry's Histoire d'un voyage fait en la terre du Brésil' calls attention to the need to revisit past translations in search of alternative voices that were eventually silenced by the European colonialist projects. The polyphonic quality of certain ethnographic texts that claim to represent cultures-such as Léry's account of the French invasion of the Americas-is an inherent feature that, rather than becoming lost in translation, is powerfully amplified when rendered in different contexts, like her analysis of Jane Whatley's English translation shows.

A third trend that is displayed in the present collection deals with the history of specific periods, as the contributions by Nitsa Ben-Ari and Lourdes Arencibia Rodríguez prove. In "Puritan Translations in Israel: Rewriting a History of Translation", the former points at eighteenth-century Victorian puritanism as the source of the peripheral position of erotic literature in the Israeli literary system and reflects on the revitalizing effect that Hebrew translations of pulp fiction and sex guides had for the vernacular canon imposed by Zionist puritanism. On the other hand, the latter takes the reader through a journey in time, back to the discovery of Christopher Columbus by America-as Bastin would put it - in "The Imperial College of Santa Cruz de Tlatelolco: The First School of Translators and Interpreters in Sixteenth-Century Spanish America" to describe the practice and place of institutional reconciliation between the natives and the missionaries: the Imperial College of Santa Cruz de Tlalelolco, the first American school of translators and interpreters, where a two-fold cultural intermingling between the colonialist project of Christianization and the collective memory of Mesoamerican communities took place.

Finally, Lydia Fossa likewise proposes a reassessment of translational activity in the history of the Americas, in this case by leaving behind ready-made concepts like "hybridism" and "transculturality" and accentuating the idea of an intersection 
of meanings and significations between two languages simultaneously, in this case Mesoamerican tongues and Spanish. With that purpose in mind, she presents the Glosas croniquenses, a post-colonial project that aims at exposing the linguistic and cultural influences that American indigenous languages exerted on the language of the colonizer, Spanish.

To conclude, the present book provides significant insights on translation and ideology as they appear in different historical times, hence broadening our tools for understanding translation as a multidimensional practice. If certainly one of the most important tasks of translators today is to denounce and correct the deceptively linear construction of history that has traditionally surrounded translation studies, Charting the Future of Translation History constitutes an excellent guide for today's professionals, providing an illustration of the paradigmatic interdependence of history and translation that hopefully will allow for a larger conceptualization of both fields in the near future.

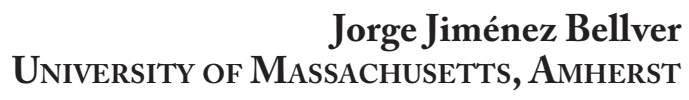

